\title{
PENATAAN KAWASAN SUMBER JENON, DESA GUNUNGRONGGO KECAMATAN TAJINAN, KABUPATEN MALANG
}

\author{
Mohammad Reza ${ }^{1}$, Agung Witjaksono ${ }^{2}$, Fardiah Qonita Ummi Naila ${ }^{3}$, Joana Angelia Putri Agustinus \\ Teweng ${ }^{4}$, I Gede Krisna Borneo Putra Pratama ${ }^{5}$, Mierta Ramadea ${ }^{6}$, Iqbal Rahmadi ${ }^{7}$, Randy Elfranda \\ Natanael ${ }^{8}$ \\ ${ }^{12345678}$ Prodi Perencanaan Wilayah dan Kota, Fakultas Teknik Sipil dan Perencanaan,

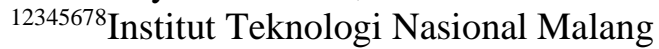

\begin{abstract}
The area of Jenon Water Source has been determined as tourism development area. This research is aimed to arrange the spatial development brief of Jenon Water Source. The method used in this research is descriptive qualitative method. The research result show that regional arranfement is needed. Where in the area arrangement in Sumber Jenon carried out in this project has a positive effect in Gunungronggo Village, which can improve the economy of the Gunungronggo Village community and improve the quality of Human Resources in Gunungronggo Village by adding a central souvenir in Sumber Jenon.
\end{abstract}

Keywords: Water Source, Improve Economy, Tourism Development Area

\section{Pendahuluan \\ Latar Belakang}

Perkembangan menjadi salah satu karakteristik yang melekat pada setiap wilayah atau kota. Perkembangan tersebut bermacam-macam, dimulai dari perkembangan penduduknya, diikuti dengan perkembangan aktivitas penduduknya dan seterusnya. Perkembangan penduduk dan aktivitasnya tersebut harus diimbangi dengan perkembangan fasilitas, karena fasilitas menjadi penunjang serta pendukung dari aktivitas penduduk tersebut. Setiap fasilitas yang dibutuhkan penduduk harus berkembang baik kuantitas maupun kualitas seiring pertambahan jumlah penduduk.

Fasilitas dan pelayanan umum merupakan berbagai bangunan fisik dan program yang terstruktur yang berperan dalam meningkatkan kenyamanan suatu lingkungan hunian. Pelayanan dan fasilitas umum dan sosial menjadi hal yang sangat penting dalam kehidupan warga kota. Pada sisi lain, pelayanan fasilitas tersebut merupakan tugas penting dan utama dari pemerintah kota setempat.

Sumber Jenon adalah salah satu mata air alami yang membentuk kolam. Kolam ini memiliki kedalaman sekitar 6,5 meter, dengan pajang sekitar $50 \mathrm{~m}$ dan lebar $30 \mathrm{~m}$. Sumber Jenon ada di kecamatan Tajinan Kabupaten Malang Jawa Timur. Dari kota Malang berjarak sekitar 30 menit perjalan menuju Cemoro Kandang atau Kecamatan Tumpang. Yang manarik di Sumber Jenon adalah suasana kolamnya yang penuh aura mistis. Kolam dikelilingi pohon-pohon beringin yang besar dan tinggi. Tajuk daunnya hampir menutupi permukaam kolam. Dedaunan yang kuning dan berguguran menambah suasana mengerikan. Di sisi lain, sumber Jenon dikeramatkan oleh masyarakat sekitar. Pada waktu-waktu tertentu ada yang memasang sesaji. Kesakralan tempat ini benarbenar dijaga untuk menjaga keutuhannya. Mitosmitos yang berkembang justru sangat menguntungkan secara ekologis yakni bisa menjaga tempat tersebut agar tetap lestari. Dengan demikian, konservasi berbasis kearifan lokal sangat efektif untuk menjaga tempat ini.

Salah satu sumber mata air yang kini menjadi sentra wisata unik dan cukup dikenal di sekitar Malang Raya. Nama Sumber Jenon sendiri diambil dari pohon jenu yang roboh dan mengeluarkan mata air. Semakin lama air tersebut semakin menggenang dan beliau membuat sungai sepanjang $4 \mathrm{~km}$ agar air dapat mengalir ke gubugnya. Proses pembuatan sungai dikerjakan dalam waktu semalam dengan ilmu yang dimiliki oleh mbah wiro. Melihat air telah mengalir, sang istri bahagia dan berfikir suaminya akan pulang. Akan tetapi yang datang hanyalah singa putih bukan suaminya. Singa putih itulah yang dianggap sebagai jelmaan dari Mbah Wiro. Sehingga desa ini disebut dengan dayangan singa putih. Jika suatu saat jaman semakin maju Mbah Wiro berpesan bahwa sumber ini akan diberi nama Sumber Jenu karena robohnya pohon jenu. Namun karena modernisasi, masyarakat sekarang ini menyebutnya Sumber Jenon. Sumber yang 
berlokasi di desa Gunung Ronggo, kecamatan Tajinan, kabupaten Malang ini seakan menawarkan tempat berendam, diving sekaligus terapi untuk berbagai penyakit, seperti penyakit kulit. Warga sekitar tidak hanya mempercayai sumber ini sebagai tempat wisata saja, tetapi juga mempercayai sebagai media penyembuhan yang mujarab.

Meskipun menyimpan keindahan dan nilai-nilai sejarah pemandian Sumber Jenon keadaannya masih kurang di perhatikan. Akses jalan setapak menuju Sumber Jenon sudah rusak dan fasilitas penunjang yang sangat kurang menjadi permasalahan dari pemandian Sumber Jenon. Tidak heran jika kondisi Sumber Jenon saat ini tidak terawat dan dibiarkan begitu saja. Tidak hanya pemerintah yang kurang memberikan perhatian, Masyarakat desa setempat pun juga terkesan acuh terhadap potensi wisata budaya Sumber Jenon.

\section{Tujuan Penelitian}

Tujuan penelitian ini adalah untuk mengidentifikasi kebutuhan fasilitas dan utilitas untuk mewujudkan pariwisata berbasis lingkungan di Sumber Jenon.

\section{Manfaat Penelitian}

Diharapkan penelitian ini dapat Memberikan informasi kepada pihak Desa Gunungronggo dalam penataan kawasan wisata Sumber Jenon sebagai sarana untuk rencana pengembangan kawasan wisata Sumber Jenon.

\section{Tinjauan Pustaka}

\section{Sumber Daya Alam}

Sumber daya alam seperti air, udara, lahan, minyak, ikan, hutan, dan lain-lain merupakan sumber daya yang sangat penting bagi kelangsungan hidup manusia. Secara umum sumber daya alam dapat diklasifikasikan ke dalam dua kelompok: Pertama, kelompok stok bahwa Sumber daya ini dianggap memiliki cadangan yang terbatas sehingga eksploitasi terhadap sumber daya tersebut akan menghabiskan cadangan sumber daya. Kedua, Kelompok kedua adalah sumber daya alam yang disebut "flows" (alur). Pada jenis sumber daya ini jumlah kuantitas fisik dari sumber daya berubah sepanjang waktu (Triastianti , Nasirudin , Sukirno , \& Warsiyah , 2017)

\section{Model Pengelolaan Sumberdaya Air}

Pengelolaan sumber daya air tawar perlu menggabungkan berbagai aspek fisik soaial dan ekonomi. Pengelolaan sumber daya air yang dapat dilakukan adalah dengan menggunakan tiga strategi yaitu, konservasi sumber daya, pengendalian pencemaran, pengaturan penggunaan dengan tiga strategi, konservasi sumber daya, pengendalian, pencemaran dan pengaturan, penggunaan dengan tiga scenario maka memelihara agar cadangan air lebih banyak, kualitas air lebih baik, dan sumber daya air dapat digunakan lebih lama (Purwadhi \& Haryani , 2017).

\section{Pariwisata}

Pariwisata adalah perjalanan yang dilakukan oleh seseorang dalam jangka waktu tertentu dari sebuah tempat ke tempat lain dengan melakukan perencanaan sebelumnya, tujuannya untuk rekreasi atau untuk sebuah kepentingan agar keinginannya bisa terpenuhi. Pariwisata tidak hanya sekadar pelayanan jasa yang disediakan oleh para pelaku industri pariwisata sebagai bentuk pemenuhan kebutuhan wisatawan baik dari sebelum berada di destinasi wisata sampai dengan ketika melakukan kegiatan wisata. Akan tetapi, terdapat faktor-faktor atau komponen kepariwisataan yang penting dalam mendukung keberhasilan pengembangan suatu wilayah sebagai destinasi pariwisata. Dalam sebuah sistem kepariwisataan terdapat enam komponen antara lain yaitu: aksesibilitas, atraksi wisata, akomodasi, fasilitas, aktivitas, layanan tambahan. (Hermawati , 2020)

\section{Metode Penelitian}

\section{Lingkup Studi dan Wilayah Penelitian}

Lingkup wilayah penelitian ini adalah Destinasi wisata sumber air jenon di Desa Gunungronggo, Kecamatan Tajinan, Kabupaten Malang

\section{Metode Penelitian dan Analisis Data}

Metode yang digunakan dalam penelitian ini adalah metode kualitatif deskriptif dengan memperlihatkan masalah yang akan dikaji. Dalam hal ini akan digunakan metode survey lapangan yang merupakan tahapan untuk memperoleh data atau keterangan pada wilayah penelitian sehingga dapat diketahui gambaran yang jelas mengenai wilayah tersebut. Data kualitatif merupakan data yang digunakan untuk mengklasifikasikan karakteristik, wujud maupun kata - kata. Meliputi data kondisi sarana dan prasarana prasarana di kawasan wisata sumber jenon. Sumber data dari penelitian ini yaitu data primer dan data sekunder, dimana data primer diperoleh melalui survei lapangan di lokasi objek wisata adalah kondisi fisik 
lingkungan survei, kondisi sarana dan prasarana pariwisata.

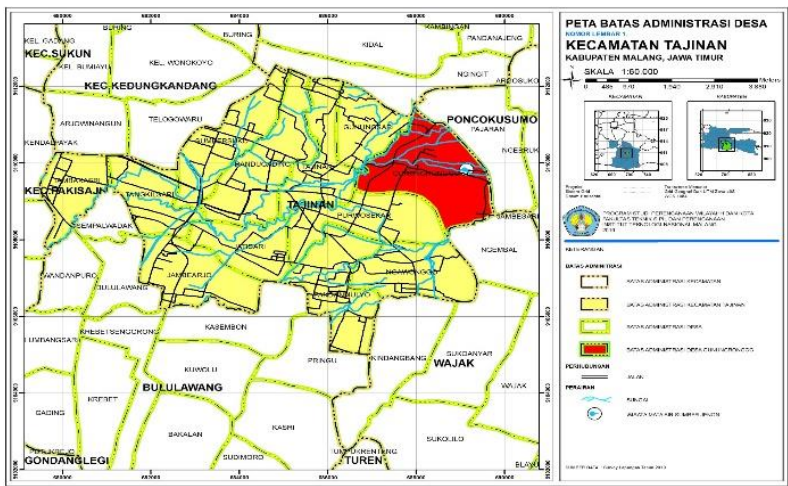

Gambar 1. Peta Batas Administrasi Kecamatan Tajinan

Sumber: Analisa 2020

\section{Hasil dan Pembahasan}

Keadaan Sosial Ekonomi Masyarakat

Mata pencaharian penduduk di Desa Gunungronggo, mayoritas adalah bertani ladang dan beternak. Sementara, Sebagian besar anak muda di Desa Gunungronggo, memilih untuk menjadi perantau ke kota sebagai buruh maupun kuli bangunan.

Rancangan Desain Kawasan Sumber Air Jenon Jalan Masuk

Sumber Jenon memang memiliki pintu masuk lalu perlu ditambahkan beberapa tanaman bunga disepanjang jalan menuju kolam. Dikarenakan jalan dari loket tiket menuju kolam agak curam sehingga dibagian sisi kanan ditambahkan anak tangga agar memudahkan pengunjung, tetapi dibagian sisi kiri tidak diubah dikarenakan mengantisipasi ada pengunjung yang membawa kereta bayi.

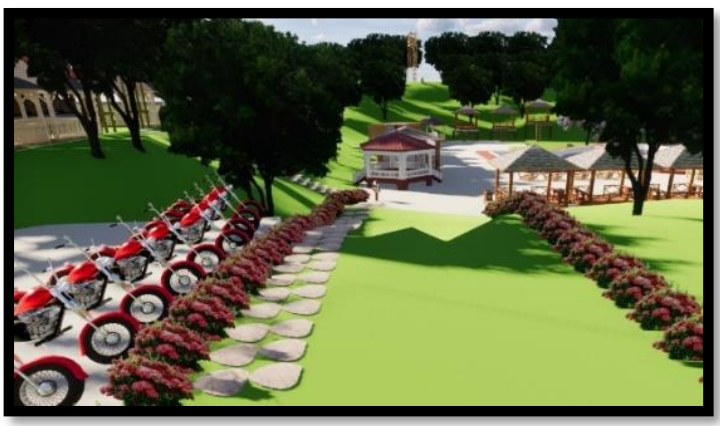

Gambar 2. Desain Gerbang Masuk Sumber Jenon Sumber: Analisa 2020

Desain Pendopo

Pendopo yang terdapat didekat kolam ditambahkan dikarenakan biasanya tidak semua pengunjung yang datang ke Sumber Jenon untuk berenang tetapi ada juga yang datang hanya untuk menikmati suasana alam yang ada di Sumber
Jenon. Jadi ditambahkan pendopo pada sisi bagian kanan dan kursi santai di sekitar kolam. Selain itu pada ujung sisi kiri terdapat tempat penyewaan alat-alat renang seperti ban, pelampung dan alat selam

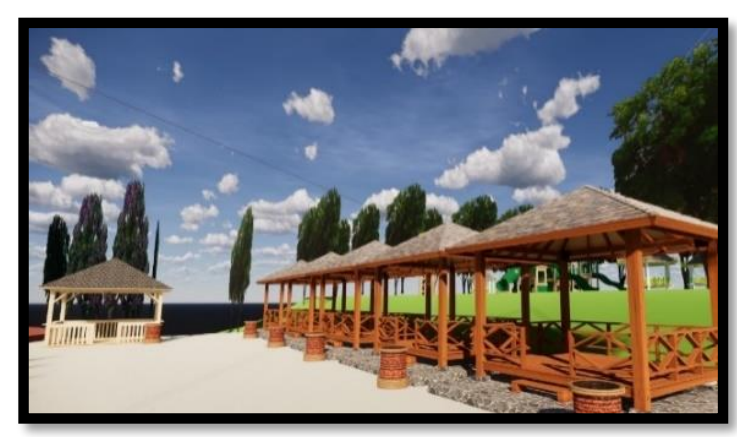

Gambar 3 Desain Pendopo dan Tempat Penyewaan Alat Renang

Sumber: Hasil Analisa 2020

Bagian Informasi dan Mushola

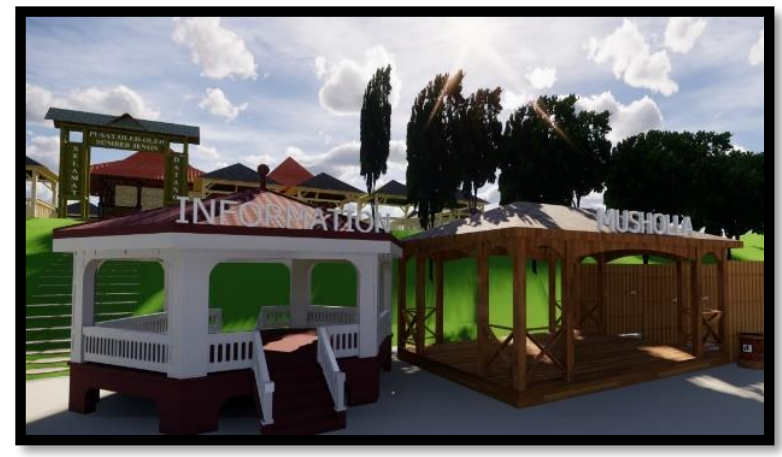

Gambar 4. Desain Bagian Informasi dan Mushola Sumber: Analisa 2020

Bagian informasi yang sudah tersedia begitu pula dengan Mushola tetapi yang perlu di perhatikan adalah letaknya agar lebih mudah dijangkau oleh pengunjung yang berada di pusat oleh-oleh maupun yang berada di dekat kolam. Tempat berwudhu dibuat secara dari bahan bambu terpisah antara laki-laki dengan perempuan

Desain Kamar Mandi

Kamar mandi umum yang terdapat di Sumber Jenon dibuat senyaman mungkin dan mudah dijangkau pengunjung, selain itu di sekitar kamar mandi umum disediakan pendopo untuk bersantai ataupun menunggu antrian untuk memasuki kamar mandi. 


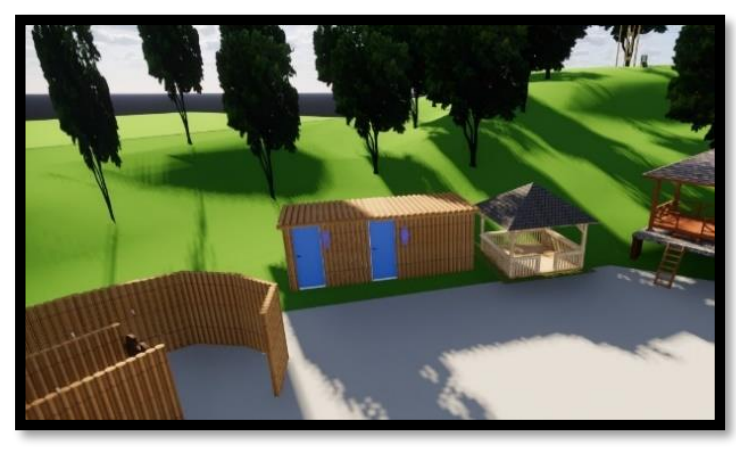

Gambar 5 Desain Kamar Mandi Umum Sumber: Hasil Analisa 2020

Kolam Sumber Air

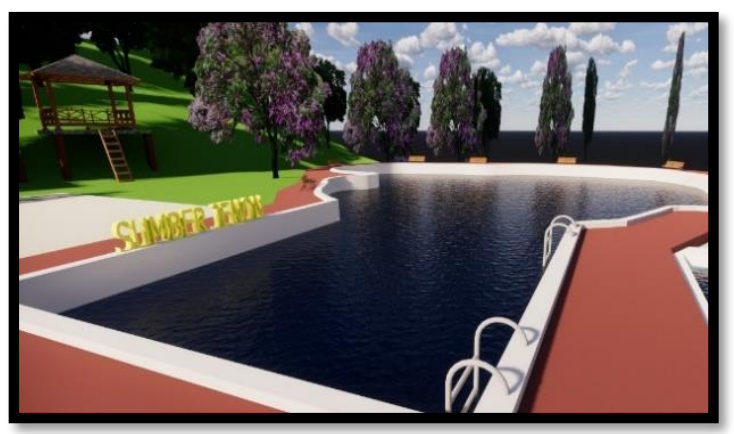

Gambar 6 Desain Kolam Sumber Air Sumber: Hasil Analisa 2020

Pada Kolam sumber jenon ini tidak memiliki perubahan bentuk akan tetapi hanya ada penambahan atribut seperti pegangan pada kolam dan kursi-kursi taman. Penambahan atribut ini ditujukan untuk memudahkan pengunjung yang ada dikolam, ataupun yang hanya duduk-duduk santai di pinggir kolam. Pusat Oleh - oleh

Penambahan pusat oleh-oleh Sumber Jenon ini diperuntukan untuk masyarakat Desa Gunungronggo dikarenakana masyarakat Desa Gunungronggo bisa menjual produk olahan khas yang bisa membantu perekonomian masyarakat. Selain itu di kawasan pusat oleh-oleh ini juga terdapat pendopo yang dapat digunakan apabila para pengunjung ingin istirahat setelah berbelanja. Pusat oleh-oleh ini dibuat menuju arah gerbang keluar sehingga apabila pengunjung ingin pulang pasti akan melewati pusat oleh-oleh ini.

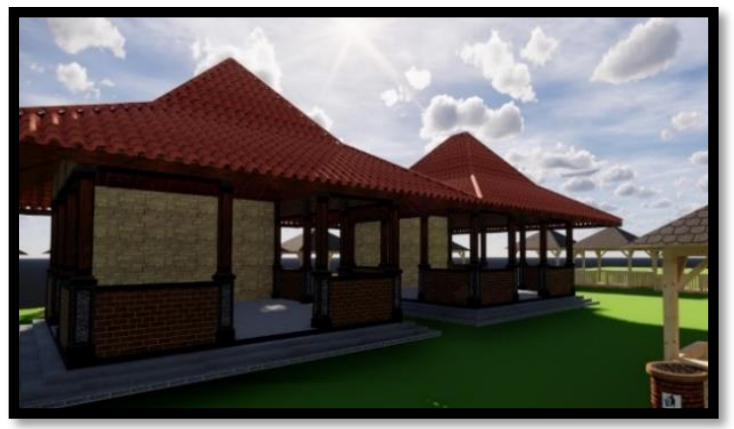

Gambar 7 Desain Pusat oleh-oleh
Sumber: Hasil Analisa 2020

Gerbang Keluar

Gerbang keluar dari pusat oleh-oleh dibuat langsung menuju ke parkiran agar memudahkan pengunjung. Selain itu melihat kondisi eksisting lokasi parkiran yang ada di Sumber Jenon yang cukup luas memungkinkan dapat menampung cukup banyak kendaraan roda dua dan kendaraan roda empat.

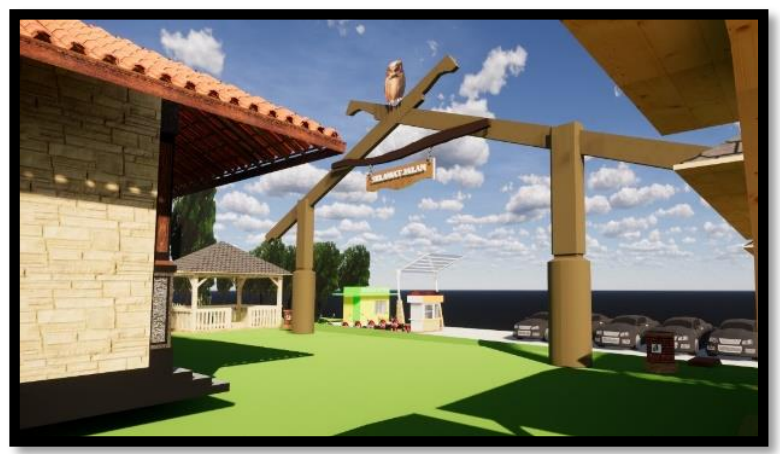

Gambar 8 Desain Gerbang Keluar Kawasan Sumber Air Jenon

Sumber: Hasil Analisa 2020

\section{Kesimpulan dan Rekomendasi Kesimpulan}

Untuk mendukung upaya dalam aktifitas Sumber Jenon berjalan dengan lancar dan lebih dikenal bukan hanya oleh masyarakat Desa Gunungronggo ataupun sekitarnya tetapi masyarakat luar daerah Malang Raya maupun wisatawan manca negara, maka dari itu perlu adanya penataan Kawasan.

Dimana dalam penataan kawasan pada Sumber Jenon dilakukan sebagai upaya ini memberikan efek positif bagi Desa Gunungronggo yaitu dapat meningkatan perekonomian masyarakat Desa Gunungronggo serta meningkatkan kualitas SDM Desa Gunungronggo dengan cara penambahan kawasan pusat oleh-oleh di Sumber Jenon. Penataan kawasan di Sumber Jenon meliputi penambahan fasilitas anak tangga di sekitar pintu masuk, letak bagian informasi dan mushola, tempat penyewaan alat renang, penambahan atribut-atribut yang ada dikolam, pusat oleh-oleh serta gerbang keluar.

\section{Rekomendasi}

Kepada pihak pengelola

Rekomendasi kepada pihak pengelola yaitu agar setiap sarana yang menunjang aktifitas kegiatan di Sumber Jenon di rawat dan di awasi sebaik mungkin agar terciptanya rasa aman dan nyaman. 
Mohammad Reza ${ }^{1}$, Agung Witjaksono ${ }^{2}$, Fardiah Qonita Ummi Naila ${ }^{3}$, Joana Angelia Putri Agustinus Teweng ${ }^{4}$, I Gede Krisna Borneo Putra Pratama ${ }^{5}$, Mierta Ramadea ${ }^{6}$, Iqbal Rahmadi ${ }^{7}$, Randy Elfranda Natanael ${ }^{8}$

\section{Kepada Pihak Desa Gunungronggo}

Untuk menjaga Sumber Jenon tetap indah dan arsi maka diperlukan kerja sama yang terpadu antar pihak pengelola, masyarakat sekitar serta pemerintah daerah demi menjaga keserasian, keseimbangan dan kelestarian yang ada di Sumber Jenon.

Kepada Pihak Dinas Pariwisata Kabupaten Malang,

dalam hal ini Dinas Pariwisata Kabupaten Malang, untuk lebih memfasilitasi wisata-wisata yang belum banyak diketahui orang-orang agar dapat lebih berkembang. Melalui pengembangan ini diharapkan menarik pengunjung lokal maupun internasional.

\section{Daftar Pustaka}

1. Hermawati , P. R. (2020). Komponen Kepariwisataan dan Pengembahan Community Based Tourism di Desa Wisata Nglanggeran . ejournal bsi , 31-43.

2. Purwadhi, F. S., \& Haryani , N. S. (2017). Penyusunan Alternatif Pengelolaan Sumber Daya Air Tawar di Pulau Nunukan Berbasis Data Inderaja dan Sistem In Form As I Geografis . 34-49.

3. Triastianti, R. D., Nasirudin, Sukirno , \& Warsiyah . (2017). Konservasi Sumber Daya Air dan Lingkungan Melalui Kearifan Lokal di Desa Margodado Kecamatan Seyegen Kabupaten Yogyakarta . Kawistara, 207-314. 